\title{
KEPUASAN KERJA MEMEDIASI PENGARUH PERCEIVED ORGANIZATIONAL SUPPORT TERHADAP ORGANIZATIONAL CITIZENSHIP BEHAVIOR PADA MARGA YUMNA ADVENTUR
}

\author{
I Putu Dharma Sadhana ${ }^{1}$ \\ I Gusti Bagus Honor Satrya ${ }^{2}$
}

${ }^{1,2}$ Fakultas Ekonomi dan Bisnis Universitas Udayana (Unud), Bali, Indonesia email: dharmasadhana13@gmail.com

\begin{abstract}
ABSTRAK
Penelitian ini dilakukan pada karyawan PT. Marga Yumna Adventur. Tujuan penelitian ini adalah untuk mengetahui pengaruh kepuasan kerja sebagai variabel mediasi antara perceived organizational support terhadap organizational citizenship behavior. Sampel yang diambil sebanyak 62 responden. Pengumpulan data dilakukan dengan penyebaran kuesioner. Teknik analisis yang digunakan adalah statistik deskriptif, analisis jalur dan uji sobel. Hasil analisis menunjukan bahwa perceived organizational support berpengaruh positif dan signifikan terhadap kepuasan kerja, hal ini mengindikasikan semakin banyak dukungan yang diberikan oleh manajemen PT. Marga Yumna Adventur maka kepuasan karyawan akan meningkat. Kepuasan kerja dan Perceived organizational support berpengaruh positif dan signifikan terhadap $O C B$, hal ini berarti bahwa semakin tinggi tingkat kepuasan yang dirasakan karyawan dan semakin banyak dukungan yang diberikan oleh manajemen PT. Marga Yumna Adventur maka semakin tinggi pula OCB yang dimiliki karyawan. Kepuasan kerja berpengaruh positif dan signifikan memediasi peran perceived organizational support terhadap $O C B$ hal ini berarti semakin banyak dukungan yang diberikan oleh manajemen PT. Marga Yumna Adventur maka kepuasan karyawan akan meningkat dan kemudian akan meninmbulkan perilaku OCB yang lebih baik pada karyawan.
\end{abstract}

Kata Kunci: perceived organizational support, kepuasan kerja, $O C B$

\begin{abstract}
This research was conducted on the employees of PT. Marga Yumna Adventur. The purpose of this study was to determine the effect of job satisfaction as a mediating variable between the perceived organizational support and organizational citizenship behavior. The samples take were as many as 62 respondents. Data collection was carried out by distributing questionnaires. The analysis technique used is descriptive statistics, path analysis and sobel test. The results of the analysis show that perceived organizational support has a positive and significant effect on job satisfaction, this indicates that the more support is given by the management of PT. Marga Yumna Adventur, employee satisfaction will increase. Job satisfaction and perceived organizational support have a positive and significant effect on $O C B$, this means that the higher the level of satisfaction felt by employees and the more support given by the management of PT. Marga Yumna Adventur, the higher the OCB employees have. Job satisfaction has a positive and significant effect mediating the role of perceived organizational support for OCB, this means that more support is given by the management of PT. Marga Yumna Adventur, employee satisfaction will increase and then will result in better OCB behavior for employees.

Keywords: perceived organizational support, job satisfaction, $O C B$
\end{abstract}




\section{PENDAHULUAN}

Sumber Daya Manusia (SDM) memiliki peran penting dalam organisasi maupun perusahaan untuk mencapai produktivitas yan tinggi bagi perusahaan Perilaku yang dapat meningkatkan produktivitas karyawan dalam perusahaan yaitu perilaku extra-role atau disebut juga perilaku Organizational Citizenship Behavior (OCB) (Harper, 2015). Terdapat beberapa variabel yang mempengaruhi (OCB) salah satunya adalah perceived organizational support. Menurut penelitan Karavardar (2014) menunjukkan bahwa perceived organizational support berpengaruh terhadap perilaku OCB pada karyawan.

Pernyataan ini sejalan dengan penelitian yang dilakukan oleh Alkerdawy (2014) pada karyawan Bank Umum Mesir, yang menemukan bahwa karyawan yang memperoleh dukungan organisasi yang tinggi akan memunculkan perilaku OCB yang tinggi pula. Persepsi dukungan organisasional juga berpengaruh bagi kepuasan karyawan, ketika karyawan yakin bahwa kesejahteraannya didukung oleh suatu organisasi maka akan menimbulkan kepuasan kerja karyawan (Waileruny, 2014). Tingginya persepsi dukungan organisasi yang dirasakan karyawan akan meningkatkan kepuasan kerja pada diri karyawan (Robbins, 2015).

Kusuma dkk. (2018) menyatakan bahwa kepuasan kerja adalah sikap positif karyawan terhadap pekerjaan dan segala sesuatu yang dihadapi di lingkungan kerjanya. Kepuasan kerja memiliki pengaruh positif dan signifikan terhadap organizational citizenship behavior (Soegandhi dkk., 2013). kepuasan kerja berpengaruh positif dan signifikan terhadap perilaku organizational citizenship behavior (Dewanggana dkk. 2016). Akan tetapi studi lain menyatakan hasil yang berbeda dengan penelitian yang sebelumnya, dimana kepuasan kerja tidak mempunyai pengaruh terhadap perilaku organizational citizenship behavior (Arif et al., 2014). Dalam penelitian Mehboob dan Bhutto (2012) menunjukkan bahwa kepuasan kerja bukanlah prediktor atau penentu utama dari OCB karena kepuasan kerja tidak berpengaruh positif dan hanya berpengaruh parsial terhadap beberapa dimensi OCB. Sehingga di perlukan analisis lebih lanjut pengaruh perceived organizational support terhadap OCB melalui kepuasan kerja (Waileruny, 2014). Karyawan yang memiliki perilaku OCB senantiasa berkontribusi positif terhadap perusahaan melalui perilaku yang bersedia untuk melakukan pekerjaan di luar dari kewajiban dan tugasnya, di samping itu karyawan tetap melaksanakan tanggung jawab dan kewajiban pekerjaan utamanya (Charmiati dan Surya, 2019).

Penelitian ini dilakukan di PT. Marga Yumna Adventur yang merupakan salah satu destinasi pariwisata yang bergerak di bidang wisata air (Rafting). PT. Marga Yumna Adventur berdiri sejak tahun 2014, yang berlokasi di Jalan Kerasan, Desa Sedang, Badung Bali. Jumlah karyawan yang berkerja di PT. Marga Yumna Adventur memiliki 62 karyawan. Divisi Operasional merupakan salah satu divisi yang sebagian besar aktivitasnya berada di lapangan. Bagian dari divisi Operasional meliputi Marketing Supervisor, Human Resource Department, Accounting, Front Office, Staff Locker, Staff Inventory, River Guide, Swing Guide, Cycling Guide, All Terrain Vehicle Guide, Cleaning Service, Gardener, Photographer, Chef, Assistant Chef Water/Waitress, Driver, porter, dan Staff Photo Counter. 
Banyak usaha sejenis yang menjadi pesaing PT. Marga Yumna Adventur, akan tetapi dengan beberapa kelebihan yang di tawarkan seperti: memiliki standar service dan keamanan yang berkulitas baik di berikan bagi wisatawan, harga yang terjangkau bagi wisatawan lokal karena adanya beberapa paket yang di berikan, menu makanan yang di berikan mengikuti trend yang ada dengan harga yang lebih murah, dan wisatawan diberikan transportasi antar-jemput dari tempat menginap. Namun dalam beberapa bulan terakhir, jumlah kunjungan wisatawan mengalami fluktuasi yang dapat dilihat dalam Gambar 1. berikut ini:

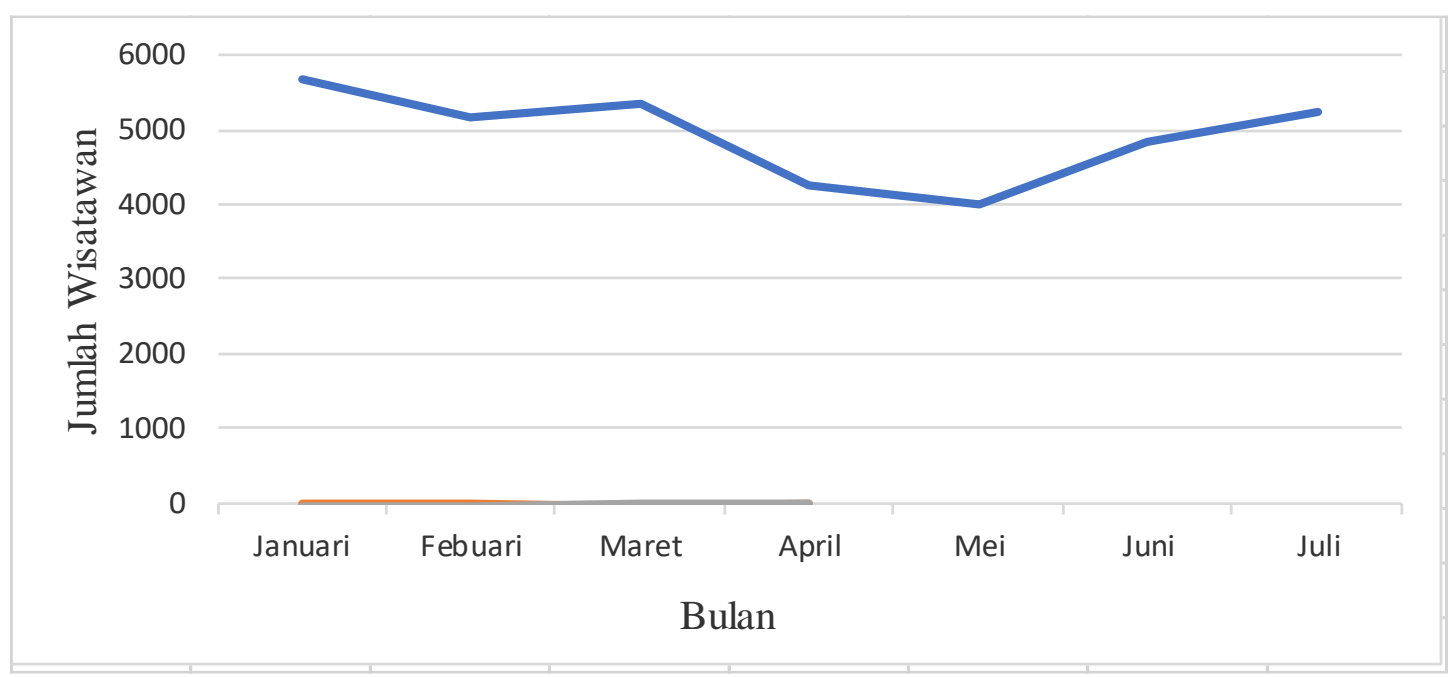

Gambar 1. Jumlah Kunjungan Wisatawan

Sumber: PT. Marga Yumna Adventur Badung, 2019

Gambar 1. menunjukkan bahwa dari bulan januari sampai juli berfluktuasinya kunjungan wisatawan disebabkan oleh beberapa faktor, salah satunya yaitu complain dari beberapa wisatawan terkait dengan perilaku dari karyawan dalam melayani wisatawan. Indikasi permasalahan mengenai OCB karyawan PT. Marga Yumna Adventur Badung disajikan pada Tabel 1. sebagai berikut.

Tabel 1.

Indikator OCB Karyawan PT. Marga Yumna Adventur Badung

\begin{tabular}{cl}
\hline Indikator OCB & \multicolumn{1}{c}{ Fakta OCB Rendah } \\
\hline Altruism & $\begin{array}{l}\text { Beberapa karyawan tidak mau membantu rekan kerja saat diminta } \\
\text { pertolongan } \\
\text { Kurangnya kesediaan menggantikan rekan kerja karena porsi kerja yang } \\
\text { bertambah ketika terdapat rekan kerja yang tidak masuk bekerja } \\
\text { Masih terdapat karyawan yang terlambat datang untuk bekerja serta } \\
\text { beberapa dari wisatawan secara serentak tidak masuk bekerja ketika ada } \\
\text { upacara adat karena sebagian besar karyawan berdomisili dalam satu } \\
\text { daerah. Kemudian masih banyaknya karyawan tidak patuh terhadap SOP } \\
\text { yang berlaku } \\
\text { Adanya keluhan dari karyawan mengenai pekerjaan atau situasi dalam } \\
\text { bekerja } \\
\text { Karyawan kurang tertarik terhadap dinamika dan inovasi jaman. }\end{array}$ \\
\hline
\end{tabular}
Sumber : Divisi HRD PT. Marga Yumna Adventur Badung, 2019. 
Berdasarkan Tabel 1. bagian indikator conscientiousness merupakan permasalahan yang sering terjadi, karena ketika kunjungan wisatawan tinggi pada musim high season maupun liburan sekolah yang tentunya diperlukan karyawan yang siap untuk melayani wisatawan akan tetapi pada saat itu juga beberapa karyawan secara serentak karena ada upacara adat, sehingga diperlukan perilaku ekstra dari karyawan lainnya untuk melaksanakan tugas diluar dari beban kerja.

Berdasarkan pra-riset melalui metode wawancara dengan sepuluh karyawan PT. Marga Yumna Adventur Badung yang terdiri dari satu karyawan departemen Human Resources Departement dan sembilan karyawan di departemen River guide berfluktuasinya jumlah kunjungan wisatawan disebabkan oleh beberapa faktor, salah satunya yaitu beberapa karyawan masih ada yang melanggar ketentuan standar operasional prosedur (SOP) perusahaan, karena ketika seorang karyawan menemani wisatawan dalam berwisata rafting, All Terrain Vehicle, swing, river guide, porter maupun cycling beberapa dari wisatawan tidak mengikuti SOP yang berlaku, sehingga para konsumen kurang nyaman terhadap pelayanan tersebut kemudian mengajukan protes kepada manager PT. Marga Yumna Adventur Badung akibat SOP yang menyalahi aturan. Oleh karena itu masih banyak ditemukan bahwa tingkat ketidakpatuhan karyawan terhadap SOP atau aturan yang berlaku di perusahaan masih cukup tinggi, dan meskipun adanya SOP yang ditetapkan perusahaan akan tetapi kadang kala wisatawan harus melanggar SOP tersebut karena untuk menyesuiakan dengan situasi dan kondisi di lapangan dengan para wisatawan, berdasarkan konteks tersebut wisatawan berasumsi bahwa kurangnya rasa kepercayaan dari atasan untuk karyawan dalam melaksanakan tugasnya, hal ini berkitan dengan teori pertukaran sosial yang dimana terdapat rasa saling percaya dan timbal balik diantara kedua belah pihak yaitu karyawan dan perusahaan (Widyaningrum, 2010).

Pada permasalahan ini dapat disimpulkan bahwa perilaku karyawan untuk mematuhi (SOP) perusahaan masih rendah, yang dimana hal tersebut dapat mempengaruhi perilaku ekstra dari karyawan itu sendiri (Sanusi dkk. 2018), untuk memunculkan OCB pada karyawan tentunya karyawan merasa puas terlebih dahulu. Aspek-aspek kepuasan kerja yaitu pekerjaan itu sendiri, gaji, pengawasan, promosi, dan kerja sama yang baik dengan rekan kerja hal ini dikemukakan oleh (Mathis dan Jackson, 2011). Sehingga perusahaan perlu memperhatikan juga mengenai dukungan organisasi serta rasa kepuasan yang di berikan kepada karyawan tersebut (Waileruny, 2014).

Berdasarkan uraian mengenai permasalahan diatas, maka tujuan penelitian ini adalah untuk menganalisis pengaruh perceived organizational support terhadap kepuasan kerja, untuk menganalisis pengaruh perceived organizational support dan kepuasan kerja terhadap organization citizenship behavior, serta untuk menganalisis peran mediasi kepuasan kerja dalam hubungan antara perceived organizational support terhadap organization citizenship behavior.

Wong dan Wong (2017) menyatakan Social exchange theory bisa digunakan untuk menjelaskan hubungan antara karyawan dengan organisasi atau perusahaannya, didasarkan pada premis dasar bahwa perilaku manusia adalah pertukaran imbalan diantara para pelakunya seperti dukungan dari organisasi, gaji, 
tunjangan dan kondisi kerja, akan melakukan timbal balik dengan sikap kerja yang positif

Lakshmi dan Simarmata (2015) menyatakan bahwa OCB merupakan suatu perilaku positif individu sebagai anggota organisasi dalam bentuk kesediaan secara sadar dan sukarela untuk bekerja dan memberikan kontribusi pada organisasi lebih daripada tuntutan yang secara formal dalam organisasi yang mendukung berfungsinya organisasi secara efektif.

Perceived organizational support dapat didefinisikan sebagai keyakinan karyawan mengenai sejauh mana perusahaan menghargai kontribusi karyawan dan peduli terhadap kesejahteraan karyawan (Oladunmoye, 2017).

Kepuasan kerja didefinisikan sebagai keadaan emosi positif yang dihasilkan dari penilaian pekerjaan atau pengalaman pekerjaan karyawan (Tripathi dan Pandey, 2017). Kepuasan kerja juga dapat diartikan sebagai selisih antara ekspektasi karyawan terhadap imbalan yang akan diterima dengan imbalan yang benar-benar karyawan terima, semakin kecil selisih tersebut maka karyawan dikatakan semakin puas (Saeed et al. 2014).

Berdasarkan telaah dan kajian penelitian terdahulu, maka dapat disusun hipotesis sebagai berikut:

$\mathrm{H}_{1}$ : Perceived Organizational Support berpengaruh positif terhadap Kepuasan Kerja.

$\mathrm{H}_{2}$ : Kepuasan kerja berpengaruh positif terhadap Organizational Citizenship Behavior.

$\mathrm{H}_{3}$ : Perceived Organizational Support berpengaruh positif terhadap Organizational Citizenship Behavior.

$\mathrm{H}_{4}$ : Kepuasan Kerja menjadi mediasi pada hubungan Perceived Organizational Support terhadap Organizational Citizenship Behavior.

Berdasarkan kajian penelitian terdahulu dan hipotesis yang sudah dirumuskan, maka model konseptual dalam penelitian ini adalah sebagai berikut:

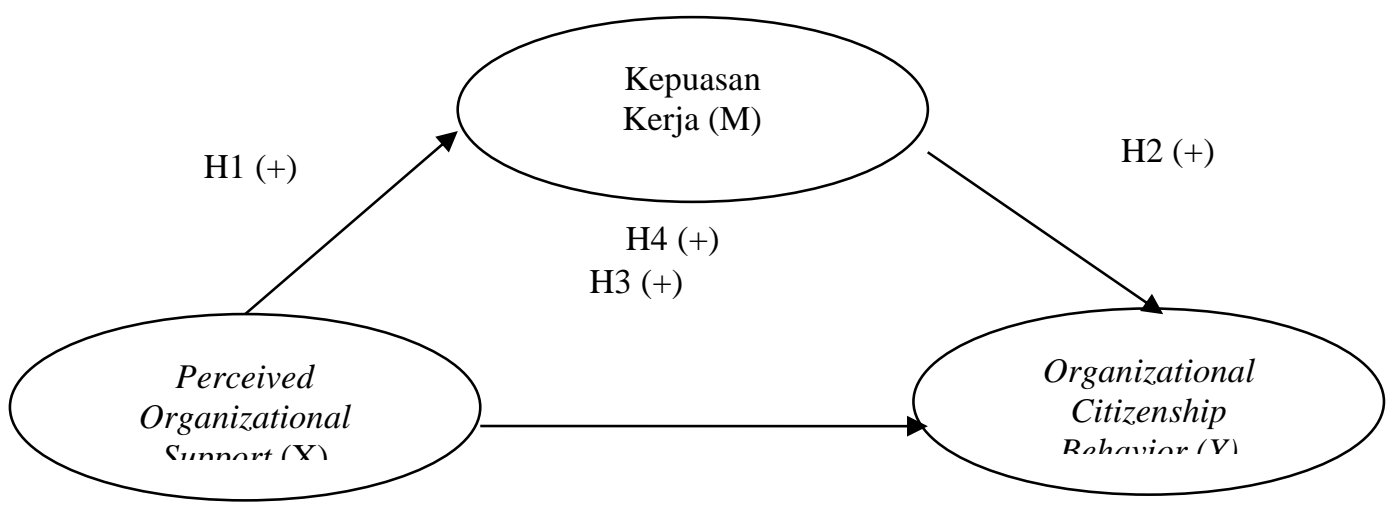

Gambar 2. Model Konseptual

Sumber : kajian penelitian terdahulu

METODE PENELITIAN 
Penelitian ini berlokasi di PT. Marga Yumna Adventur yang bergerak di bidang pariwisata dan beralamat di Jalan Kerasan, Desa Sedang, Badung Bali, Indonesia. Variabel yang diteliti dalam penelitian ini adalah Perceived Organizational Support (X) sebagai variabel bebas, Kepuasan kerja (M) sebagai variabel mediasi, serta Organizational Citizenship Behavior (Y) sebagai variabel terikat, dengan indikator yang digunakan sebagai berikut.

Tabel 2.

\section{Rangkuman Variabel dan Indikator Penelitian}

\begin{tabular}{|c|c|c|c|}
\hline No & Variabel & Indikator & Sumber \\
\hline 1. & $\begin{array}{l}\text { Organizational } \\
\text { Citizenship } \\
\text { Behavior (Y) }\end{array}$ & $\begin{array}{l}\text { 1. Altruism } \\
\text { 2. Conscientiousness } \\
\text { 3. Sportmanship } \\
\text { 4. Courtesy } \\
\text { 5. Civic Virtue }\end{array}$ & $\begin{array}{l}\text { Organ, et } \\
a l,(2006)\end{array}$ \\
\hline 2. & $\begin{array}{l}\text { Kepuasan } \\
\text { Kerja (M) }\end{array}$ & $\begin{array}{l}\text { 1. Upah } \\
\text { 2. Pengawasan } \\
\text { 3. Pekerjaan } \\
\text { 4. Rekan kerja } \\
\text { 5. Promosi }\end{array}$ & $\begin{array}{c}\text { Robbins } \\
\text { dan Judge, } \\
(2008: 171)\end{array}$ \\
\hline 3. & $\begin{array}{c}\text { Perceived } \\
\text { Organizational } \\
\text { Support }(\mathrm{X})\end{array}$ & $\begin{array}{l}\text { 1. Organisasi menghargai kontribusi karyawan } \\
\text { 2. Organisasi menghargai usaha ekstra karyawan } \\
\text { 3. Organisasi akan memperhatikan keluhan karyawan } \\
\text { 4. Organisasi sangat peduli kesejahteraan karyawan } \\
\text { 5. Organisasi akan memberitahu karyawan apabila tidak } \\
\text { melakukan pekerjaan dengan baik } \\
\text { 6. Organisasi peduli akan kepuasan secara umum } \\
\text { terhadap pekerjaan karyawan } \\
\text { 7. Organisasi menunjukan perhatian besar pada } \\
\text { karyawan kananan } \\
\text { 8. Organisasi merasa bangga atas keberasilan karyawan } \\
\text { dalam bekerja }\end{array}$ & $\begin{array}{c}\text { Rhoades } \\
\text { dan } \\
\text { Eisenberger } \\
(2002)\end{array}$ \\
\hline
\end{tabular}

Sumber: Kajian penelitian sebelumnya, 2020

Populasi dalam penelitian ini adalah karyawan di PT. Marga Yumna Adventur yang berjumlah sebanyak 62 orang. Sampel yang digunakan dalam penelitian ini adalah seluruh karyawan PT. Marga Yumna Adventur yang berjumlah 62 orang. Dalam penelitian ini menggunakan metode penentuan sampling jenuh, yaitu teknik penentuan sampel bila semua anggota populasi digunakan sebagai sampel. Pengumpulan data dilakukan dengan penyebaran kuesioner. Pada penelitian ini digunakan teknik analisis data berupa teknik analisis jalur atau disebut sebagai Path Analysis, dengan melakukan uji instrumen penelitian (uji validitas dan reliabilitas) dan analisis statistik deskriptif sebelumnya melakukan pengujian hipotesis dengan analisis jalur.

\section{HASIL DAN PEMBAHASAN}

Penelitian ini menggunakan 62 orang karyawan pada PT. Marga Yumna Adventur sebagai responden sesuai dengan ukuran sampel yang digunakan. Penggambaran mengenai responden dalam penelitian ini akan dijelaskan dengan 
menyajikan karakteristik responden yang didasarkan pada tiga aspek yaitu umur, jenis kelamin dan pendidikan terakhir.

Tabel 3.

Karakteristik Responden PT. Marga Yumna Adventur

\begin{tabular}{|c|c|c|c|c|}
\hline No. & \multicolumn{2}{|c|}{ Kriteria } & $\begin{array}{c}\text { Jumlah Responden } \\
\text { (Orang) }\end{array}$ & $\begin{array}{c}\text { Persentase Responden } \\
(\%)\end{array}$ \\
\hline 1 & \multirow{5}{*}{ Usia } & 19 - 23 Tahun & 15 & 24,20 \\
\hline 2 & & 24 - 28 Tahun & 32 & 51,62 \\
\hline 3 & & 29 - 33 Tahun & 13 & 20,96 \\
\hline \multirow[t]{2}{*}{4} & & $\geq 34$ Tahun & 2 & 3,22 \\
\hline & & Jumlah & 62 & 100 \\
\hline 1 & \multirow{3}{*}{ Jenis Kelamin } & Laki-Laki & 49 & 79,03 \\
\hline \multirow[t]{2}{*}{2} & & Perempuan & 13 & 20,97 \\
\hline & & Jumlah & 62 & 100 \\
\hline 1 & \multirow{5}{*}{$\begin{array}{c}\text { Pendidikan } \\
\text { Terakhir }\end{array}$} & SMP & 2 & 3,22 \\
\hline 2 & & SMA/SMK & 51 & 82,26 \\
\hline 3 & & Diploma & 6 & 9,68 \\
\hline 4 & & Sarjana & 3 & 4,84 \\
\hline & & Jumlah & 62 & 100 \\
\hline
\end{tabular}

Sumber: Data primer diolah, 2020

Tabel 3. menunjukkan sebagian besar responden dalam penelitian ini berusia 24 sampai 28 tahun dengan persentase sebesar 51,62 persen atau sebanyak 32 orang yang merupakan kelompok dalam usia produktif yang berarti sudah memiliki pengalaman yang cukup dalam bekerja sehingga mampu bekerja dengan baik. Penelitian ini didominasi dengan responden berjenis kelamin laki-laki dengan keseluruhan persentase sebesar 79,03 persen atau 49 orang karena perusahaan ini para pekerjanya sebagian besar merupakan river guide.. Pendidikan terakhir responden sebagian besar merupakan lulusan SMA/SMK dengan persentase sebesar 82,26 persen atau 51 orang, seseorang yang sudah menempuh pendidikan hingga jenjang SMA diasumsikan memiliki pemahaman dan kemampuan yang cukup baik dalam menyelesaikan pekerjaan.

Hasil uji validitas pada tabel 4 menunjukkan bahwa seluruh instrumen penelitian yang digunakan untuk mengukur variabel Perceived Organizational Support, Kepuasan kerja dan Organizational Citizenship Behavior memiliki nilai koefisien korelasi dengan skor total seluruh item pernyataan lebih besar dari 0,30 dan memiliki koefisien Cronbach's Alpha lebih dari 0,60. Hal ini menunjukkan bahwa butir-butir pernyataan dalam instrument penelitian tersebut valid dan reliabel, sehingga layak digunakan sebagai instrument penelitian.

Berdasarkan jawaban responden pada variabel Organizational Citizenship Behavior (OCB) pada Tabel 6. secara keseluruhan memiliki rata-rata sebesar 3,99 yang berarti niat karyawan untuk membantu rekan kerja dan bekerja melebihi tugastugas yang diberikan tergolong dalam kriteria tinggi diukur dari skala 1-5. Intensitas kondisi indikator Organizational Citizenship Behaviour yang menunjukkan level Organizational Citizenship Behaviour sangat rendah sampai level Organizational Citizenship Behaviour tinggi. 
Tabel 4.

Hasil Uji Validitas dan Reliabilitas

\begin{tabular}{cccccc}
\hline Variabel & Indikator & Korelasi & Sig. & Cronbach's Alpha & Keterangan \\
\hline & $\mathrm{X}_{1}$ & 0,845 & 0,000 & & \\
& $\mathrm{X}_{2}$ & 0,842 & 0,000 & & \\
Perceived & $\mathrm{X}_{3}$ & 0,875 & 0,000 & & Valid dan \\
Organizational & $\mathrm{X}_{4}$ & 0,796 & 0,000 & 0,928 & Reliabel \\
Support (X) & $\mathrm{X} 5$ & 0,642 & 0,000 & & \\
& $\mathrm{X} 6$ & 0,896 & 0,000 & & \\
& $\mathrm{X} 7$ & 0,895 & 0,000 & & Valid dan \\
& $\mathrm{X} 8$ & 0,723 & 0,000 & & \\
Kepuasan kerja & $\mathrm{M}_{1}$ & 0,899 & 0,000 & & \\
(M) & $\mathrm{M}_{2}$ & 0,811 & 0,000 & & \\
& $\mathrm{M}_{3}$ & 0,882 & 0,000 & 0,870 & Ralid dan \\
& $\mathrm{M}_{4}$ & 0,775 & 0,000 & & \\
Organizational & $\mathrm{M}_{5}$ & 0,686 & 0,000 & & \\
Citizenship & $\mathrm{Y}_{1}$ & 0,870 & 0,000 & & \\
Behavior (Y) & $\mathrm{Y}_{2}$ & 0,883 & 0,000 & & \\
& $\mathrm{Y}_{3}$ & 0,871 & 0,000 & 0,918 & \\
& $\mathrm{Y}_{4}$ & 0,830 & 0,000 & & \\
\hline
\end{tabular}

Sumber : Data diolah, 2020

Tabel 5.

Kriteria Pengukuran Deskripsi Variabel Penelitian

\begin{tabular}{ccc}
\hline No. & Skala Pengukuran & Kriteria \\
\hline 1 & $1,00-1,79$ & Sangat Rendah \\
2 & $1,80-2,59$ & Rendah \\
3 & $2,60-3,39$ & Sedang \\
4 & $3,40-4,19$ & Tinggi \\
5 & $4,20-5,00$ & Sangat Tinggi \\
\hline
\end{tabular}

Sumber : Data diolah, 2018

Pengumpulan data melalui kuesioner yang terdiri atas pernyataan responden berdasarkan masing-masing variabel secara rinci dijabarkan pada Tabel 6 .

Rata-rata jawaban tertinggi karyawan terdapat pada pernyataan Y.1 yaitu "Saya memberikan pertolongan kepada rekan kerja yang sedang mengalami kesulitan" dengan nilai skor rata-rata 4,37. Hal ini menunjukkan bahwa dalam pernyataan diatas karyawan setuju dengan memberikan pertolongan kepada rekan kerja yang sedang mengalami kesulitan dengan sukarela tanpa mengharapkan imbalan. Nilai skor paling rendah ditunjukkan pada pernyataan Y.5 yaitu "Saya mengikuti perubahan dan perkembangan dalam organisasi" dengan skor 3.95. Hal ini menunjukan bahwa beberapa responden merasa kurang memiliki keinginan untuk perubahan dan perkembangan dalam organisasi

Selanjutnya deskripsi jawaban responden terhadap variabel perceives organizational support dapat dilihat pada Tabel 7. sebagai berikut. 
Tabel 6.

Deskripsi Variabel Organizational Citizenship Behavior (Y)

\begin{tabular}{|c|c|c|c|c|c|c|c|c|c|}
\hline \multirow{2}{*}{ No } & \multirow{2}{*}{ Pernyataan } & \multicolumn{5}{|c|}{ Skor Jawaban } & \multirow{2}{*}{$\begin{array}{c}\text { Jumlah } \\
\text { Skor }\end{array}$} & \multirow{2}{*}{$\begin{array}{l}\text { Rata- } \\
\text { Rata }\end{array}$} & \multirow{2}{*}{ Kriteria } \\
\hline & & STS & TS & $\mathbf{N}$ & $\mathbf{S}$ & SS & & & \\
\hline 1. & $\begin{array}{l}\text { Saya memberikan } \\
\text { pertolongan kepada rekan } \\
\text { kerja yang sedang } \\
\text { mengalami kesulitan. }\end{array}$ & 0 & 4 & 7 & 13 & 38 & 271 & 4,37 & $\begin{array}{l}\text { Sangat } \\
\text { tinggi }\end{array}$ \\
\hline 2. & $\begin{array}{l}\text { Saya patuh terhadap aturan } \\
\text { yang berlaku di organisasi. }\end{array}$ & 2 & 4 & 12 & 19 & 25 & 247 & 3,98 & Tinggi \\
\hline 3. & $\begin{array}{l}\text { Saya tidak mengeluh } \\
\text { tentang segala sesuatu yang } \\
\text { terjadi dalam organisasi. }\end{array}$ & 6 & 10 & 13 & 17 & 16 & 213 & 3,43 & Tinggi \\
\hline 4. & $\begin{array}{l}\text { Saya menjaga hubungan } \\
\text { baik dengan rekan kerja } \\
\text { agar terhindar dari masalah } \\
\text { interpersonal. }\end{array}$ & 1 & 2 & 8 & 22 & 29 & 262 & 4,22 & $\begin{array}{l}\text { Sangat } \\
\text { tinggi }\end{array}$ \\
\hline 5. & $\begin{array}{l}\text { Saya mengikuti perubahan } \\
\text { dan perkembangan dalam } \\
\text { organisasi. }\end{array}$ & 3 & 3 & 15 & 14 & 27 & 245 & 3,95 & Tinggi \\
\hline \multicolumn{8}{|c|}{ Rata-rata } & 3.99 & Tinggi \\
\hline
\end{tabular}

Tabel 7.

Deskripsi Variabel Perceived Organizational Support (X)

\begin{tabular}{|c|c|c|c|c|c|c|c|c|c|}
\hline \multirow{2}{*}{ No. } & \multirow{2}{*}{ Pernyataan } & \multicolumn{5}{|c|}{ Skor Jawaban } & \multirow{2}{*}{$\begin{array}{c}\text { Jumlah } \\
\text { Skor }\end{array}$} & \multirow{2}{*}{$\begin{array}{l}\text { Rata- } \\
\text { Rata }\end{array}$} & \multirow{2}{*}{ Kriteria } \\
\hline & & STS & TS & $\mathbf{N}$ & $\mathbf{S}$ & SS & & & \\
\hline 1. & $\begin{array}{l}\text { Organisasi menghargai } \\
\text { kontribusi saya. }\end{array}$ & 1 & 2 & 12 & 25 & 22 & 251 & 4,04 & Tinggi \\
\hline 2. & $\begin{array}{l}\text { Organisasi menghargai } \\
\text { usaha ekstra yang saya } \\
\text { berikan. }\end{array}$ & 1 & 1 & 18 & 20 & 22 & 247 & 3,98 & Tinggi \\
\hline 3. & $\begin{array}{l}\text { memperhatikan segala } \\
\text { keluhan saya. }\end{array}$ & 2 & 4 & 14 & 20 & 22 & 242 & 3,90 & Tinggi \\
\hline 4. & $\begin{array}{l}\text { Organisasi peduli tentang } \\
\text { kesejahteraan saya. } \\
\text { Organisasi memberitahu }\end{array}$ & 1 & 2 & 14 & 21 & 24 & 251 & 4,04 & Tinggi \\
\hline 5. & $\begin{array}{l}\text { saya, jika saya tidak } \\
\text { melakukan pekerjaan } \\
\text { dengan baik. }\end{array}$ & 1 & 2 & 10 & 30 & 19 & 250 & 4,03 & Tinggi \\
\hline 6. & $\begin{array}{l}\text { Organisasi peduli dengan } \\
\text { kepuasan saya terhadap } \\
\text { pekerjaan yang saya } \\
\text { lakukan. }\end{array}$ & 0 & 5 & 15 & 25 & 17 & 240 & 3,87 & Tinggi \\
\hline 7 & $\begin{array}{l}\text { Organisasi menunjukan } \\
\text { perhatian yang besar } \\
\text { pada kinerja saya. }\end{array}$ & 1 & 0 & 15 & 23 & 23 & 253 & 4,08 & Tinggi \\
\hline 8 & $\begin{array}{l}\text { Organisasi merasa } \\
\text { bangga atas keberhasilan } \\
\text { saya di dalam melakukan } \\
\text { pekeriaan. }\end{array}$ & 1 & 1 & 13 & 29 & 18 & 248 & 4,00 & Tinggi \\
\hline \multicolumn{8}{|c|}{ Rata-rata } & 3,99 & Tinggi \\
\hline
\end{tabular}


Berdasarkan jawaban responden pada variabel perceived organizational support pada Tabel 7. secara keseluruhan memiliki rata-rata sebesar 3,99 yang berarti persepsi karyawan terhadap sejauhmana organisasi memberikan dukungan terhadap karyawan tergolong dalam kriteria baik. Intensitas kondisi indikator perceived organizational yang menunjukkan level perceived organizational sangat rendah - level perceived organizational sangat tinggi. Rata-rata jawaban tertinggi karyawan terdapat pada pernyataan X.7 yaitu "Organisasi menunjukan perhatian yang besar pada kinerja saya" dengan nilai skor rata-rata 4,08. Hal ini menunjukkan bahwa dalam pernyataan diatas karyawan setuju dengan organisasi memberikan perhatian terhadap kinerja karyawan. Nilai skor paling rendah ditunjukkan pada pernyataan X.6 yaiyu "Organisasi peduli dengan kepuasan saya terhadap pekerjaan yang saya lakukan." dengan skor 3,87. Hal ini menunjukkan bahwa beberapa responden merasa kurang organisasi kurang peduli dengan kepuasan karyawan terhadap pekerjaan yang dilakukan karyawan.

Tabel 8.

Deskripsi Variabel Kepuasan Kerja (M)

\begin{tabular}{|c|c|c|c|c|c|c|c|c|c|}
\hline \multirow[t]{2}{*}{ No } & \multirow{2}{*}{ Pernyataan } & \multicolumn{5}{|c|}{ Skor Jawaban } & \multirow{2}{*}{$\begin{array}{c}\text { Jumlah } \\
\text { Skor }\end{array}$} & \multirow{2}{*}{$\begin{array}{l}\text { Rata- } \\
\text { Rata }\end{array}$} & \multirow{2}{*}{ Kriteria } \\
\hline & & STS & TS & $\mathbf{N}$ & $\mathbf{S}$ & SS & & & \\
\hline 1. & $\begin{array}{l}\text { Upah yang saya terima sudah sesuai } \\
\text { dengan beban pekerjaan saya }\end{array}$ & 3 & 8 & 12 & 17 & 22 & 233 & 3,75 & Tinggi \\
\hline 2. & $\begin{array}{l}\text { Atasan melakukan pengawasan } \\
\text { menyeluruh terhadap pekerjaan yang } \\
\text { saya lakukan }\end{array}$ & 1 & 2 & 16 & 26 & 17 & 242 & 3,90 & Tinggi \\
\hline 3. & $\begin{array}{l}\text { Saya merasa pekerjaan yang } \\
\text { dibebankan oleh perusahaan sesuai } \\
\text { dengan kemampuan saya }\end{array}$ & 3 & 1 & 11 & 22 & 25 & 251 & 4,04 & Tinggi \\
\hline 4. & $\begin{array}{l}\text { Saya merasa hubungan antar rekan } \\
\text { kerja saya terjalin dengan baik }\end{array}$ & 2 & 2 & 10 & 19 & 29 & 257 & 4,14 & Tinggi \\
\hline 5. & $\begin{array}{l}\text { Saya puas dengan kesempatan yang } \\
\text { diberikan oleh perusahaan untuk } \\
\text { mendapatkan promosi }\end{array}$ & 1 & 2 & 14 & 22 & 23 & 250 & 4,03 & Tinggi \\
\hline \multicolumn{8}{|c|}{ Rata-rata } & 3,97 & Tinggi \\
\hline
\end{tabular}

Sumber: Hasil Olahan Data, 2020

Berdasarkan jawaban reponden pada variabel kepuasan kerjapada Tabel 8 secara keseluruhan memiliki rata-rata sebesar 3,97 yang berarti sikap emosional positif yang membuat karyawan menyenangi pekerjaan yang dilakukan karena wisatawan merasa senang dalam melakukan pekerjaannya tergolong dalam kriteria tinggi. Rata-rata jawaban tertinggi karyawan terdapat pada pernyataan M.4 yaitu "Saya merasa hubungan antar rekan kerja saya terjalin dengan baik" dengan nilai skor rata-rata 4,14 . Hal ini menunjukkan bahwa dalam pernyataan diatas karyawan setuju dengan hubungan antar rekan kerja terjalin dengan baik. Nilai skor paling rendah ditunjukkan pada pernyataan M.1 yaitu "Upah yang saya terima sudah sesuai dengan beban pekerjaan saya" dengan skor 3,75. Hal ini menunjukkan bahwa beberapa responden merasa kurang menerima kompensasi yang diberikan tidak sesuai dengan beban kerja yang diberikan.

Akan tetapi dari analisa tabel diatas muncul masalah yang sering terjadi juga dapat ditunjukan bedasarkan jawaban responden pada butir-butir pernyataan M.1 
"Upah yang saya terima sudah sesuai dengan beban pekerjaan saya" yang menjawab sangat tidak setuju tiga orang karyawan, yang menjawab tidak setuju delapan orang dan yang menjawab netral dua belas orang karyawan. Berdasarkan pertanyaan M.1 bahwa beberapa responden masih merasakan kuranganya mendapatkan kompensasi yang tepat dengan beban pekerjaan yang diberikan perusahaan contohnya dibagian river guide beban kerja yang berat dalam memebrikan arahan-arahan kepada wisatawan tentang keselamatan pada saat rafting namun kompensasi yang diterima tidak sesuai dengan beban kerja yang diterima. Pada pertanyaan M.2 yaitu "Atasan melakukan pengawasan menyeluruh terhadap pekerjaan yang saya lakukan" maka terdapat ada satu orang karyawan yang menjawab sangat tidak setuju, dua orang karyawan menjawab tidak setuju, dan enam belas orang karyawan menjawab netral. Hal ini menunjukan bahwa perusahan kurang melakukan pengawasan menyeluruh terhadap pekerjaan yang dilakukan karyawan contohnya manajer kurang mengawasi dibagian river guide tentang memberikan keselamatan wisatawan pada saat rafting.

Pertanyaan M.3 "Saya merasa pekerjaan yang dibebankan oleh perusahaan sesuai dengan kamampuan saya" maka terdapat ada tiga orang karyawan menjawab tidak setuju, satu orang karyawan menjawab tidak setuju dan sebelas orang karyawan menjawab netral. Hal ini menjelaskan bahwa beberapa responden merasakan pekerjaan yang dibebankan tidak sesuai dengan kemampuan karyawan dikarenakan beban kerja yang diberikan oleh perusahan terlalu banyak yang menyebabkan karyawan tidak bisa menyelesaikan pekerjaannya secara maksimal.

Pertanyaan M.4 yaitu "Saya merasa hubungan antar rekan kerja saya terjalin dengan baik" maka terdapat ada dua orang karyawan menjawab sangat tidak setuju, dua orang karyawan menjawab tidak setuju dan sepuluh orang karyawan menjawab netral. Hal ini menegaskan bahwa beberapa responden merasakan hubungan antar rekan kerja kurang terjalin dengan baik contohnya ada beberapa karyawan yang merasa iri hati antar rekan kerja seperti manajer yang memperilakukan berbeda pada karyawan satu dengan karyawan lainnya.

Bahkan pernyataan M.5 yaitu "Saya puas dengan kesempatan yang diberikan oleh perusahaan untuk mendapatkan promosi" maka terdapat ada satu orang karyawan menjawab sangat tidak setuju, dua orang karyawan menjawab tidak setuju dan empat belas orang karyawan menjawab netral. Hal ini menunjukan bahwa beberapa responden kurang puas dengan kesempatan yang diberikan oleh perusahaan untuk mendapatkan promosi jabatan, dikarenakan perusahaan tersebut tidak menekankan suatu promosi jabatan di dalam hasil pencapaian tugas.

Berdasarkan hasil analisis jalur substruktur 1 seperti yang disajikan pada Tabel 9, maka dapat dibuat persamaan struktural sebagai berikut : $\mathrm{M}=0,844 \mathrm{X}+\mathrm{e}_{1}$

Nilai koefisien regresi variabel perceived organizational support bernilai positif dengan nilai signifikansi uji t kurang dari 0,05. Hal ini menunjukkan bahwa variabel perceived organizational support memiliki pengaruh positif yang signifikan terhadap variabel kepuasan kerja. Besarnya pengaruh variabel bebas terhadap variabel terikat yang ditunjukkan oleh nilai determinasi total (R Square) sebesar 0,712 mempunyai arti bahwa sebesar 71,2 persen variasi kepuasan kerja 
dipengaruhi oleh variasi perceived organizational support, sedangkan sisanya sebesar 28,8 persen dijelaskan oleh faktor lain yang tidak diteliti.

Tabel 9.

Hasil Analisis Jalur 1

\begin{tabular}{|c|c|c|c|c|c|}
\hline \multirow[t]{2}{*}{ Variabel } & \multicolumn{2}{|c|}{$\begin{array}{c}\text { Unstandardized } \\
\text { Coefficients }\end{array}$} & \multirow{2}{*}{$\begin{array}{c}\begin{array}{c}\text { Standardized } \\
\text { Coefficients }\end{array} \\
\text { Beta } \\
\end{array}$} & \multirow[b]{2}{*}{$\mathbf{T}$} & \multirow[b]{2}{*}{ Sig. } \\
\hline & $\mathbf{B}$ & Std. Error & & & \\
\hline (Constant) & .128 & .321 & & .398 & .692 \\
\hline $\begin{array}{l}\text { Perceived Organizational } \\
\text { Support }(\mathrm{X})\end{array}$ & .963 & .079 & .844 & 12.183 & .000 \\
\hline Dependen Variabel & & & Kepuasan kerja & & \\
\hline R Square & & & 0,712 & & \\
\hline Adjusted R Square & & & 0,707 & & \\
\hline F Statistik & & & 148,422 & & \\
\hline Signifikansi Uji F & & & 0,000 & & \\
\hline
\end{tabular}

Tabel 10.

Hasil Analisis Jalur 2

\begin{tabular}{|c|c|c|c|c|c|}
\hline \multirow[t]{2}{*}{ Variabel } & \multicolumn{2}{|c|}{$\begin{array}{c}\text { Unstandardized } \\
\text { Coefficients }\end{array}$} & \multirow{2}{*}{$\begin{array}{c}\begin{array}{c}\text { Standardized } \\
\text { Coefficients }\end{array} \\
\text { Beta } \\
\end{array}$} & \multirow[b]{2}{*}{$\mathbf{t}$} & \multirow[b]{2}{*}{ Sig. } \\
\hline & B & $\begin{array}{l}\text { Std. } \\
\text { Error }\end{array}$ & & & \\
\hline (Constant) & .013 & .325 & & .041 & .967 \\
\hline Perceived Organizational Support & .678 & .149 & .576 & .556 & .000 \\
\hline Kepuasan kerja & .320 & .130 & .310 & .452 & .017 \\
\hline $\begin{array}{l}\text { Dependen variable } \\
\text { R Square } \\
\text { Adjusted R Square } \\
\text { F Statistik } \\
\text { Signifikansi Uji F }\end{array}$ & Orgar & $\begin{array}{r}\text { itional } C i \\
0, \\
0, \\
79, \\
0, \\
\end{array}$ & $\begin{array}{l}\text { enship Behavior } \\
0 \\
0\end{array}$ & & \\
\hline
\end{tabular}

Sumber: Hasil Olahan Data, 2020

Berdasarkan hasil analisis jalur substruktur 2 seperti yang disajikan pada Tabel 10, maka dapat dibuat persamaan struktural sebagai berikut :

$$
\mathrm{Y}=0,576 \mathrm{X}+0,310 \mathrm{M}+\mathrm{e}_{2}
$$

Nilai signifikansi masing-masing variabel bebas kurang dari 0,050. Hal ini menunjukkan bahwa semua variabel bebas memiliki pengaruh yang signifikan terhadap variabel terikat. Besarnya pengaruh variabel bebas terhadap variabel terikat yang ditunjukkan oleh nilai determinasi total ( $R$ Square) sebesar 0,729 mempunyai arti bahwa sebesar 72,9 persen variasi organizational citizenship behavior dipengaruhi oleh variasi perceived organizational support dan kepuasan kerja, sedangkan sisanya sebesar 27,1 persen dijelaskan oleh faktor lain yang tidak dimasukkan ke dalam model.

Berdasarkan model substruktur 1 dan substruktur 2, maka dapat disusun model diagram jalur akhir. Sebelum menyusun model diagram jalur akhir, terlebih dahulu dihitung nilai standar eror sebagai berikut : 


$$
\begin{aligned}
& \mathrm{Pe}_{1}=\sqrt{1-R_{1}{ }^{2}}=\sqrt{1-0,712}=0,536 \\
& \mathrm{Pe}_{2}=\sqrt{1-R_{2}{ }^{2}}=\sqrt{1-0,729}=0,849
\end{aligned}
$$

Berdasarkan perhitungan pengaruh error (Pei), didapatkan hasil pengaruh error $\left(\mathrm{Pe}_{1}\right)$ sebesar 0,768 dan pengaruh error $\left(\mathrm{Pe}_{2}\right)$ sebesar 0,849. Hasil koefisien determinasi total adalah sebagai berikut :

$$
\begin{aligned}
\mathrm{R}^{2}{ }_{\mathrm{m}} & =1-\left(\mathrm{Pe}_{1}\right)^{2}\left(\mathrm{Pe}_{2}\right)^{2} \\
& =1-(0,536)^{2}(0,849)^{2} \\
& =1-(0,287)(0,721) \\
& =1-0,207=0,793
\end{aligned}
$$

Nilai determinasi total sebesar 0,793 mempunyai arti bahwa sebesar 79,3 persen variasi organizational citizenship behavior pada PT. Marga Yumna Adventur dipengaruhi oleh variasi perceived organizational support dan kepuasan kerja, sedangkan sisanya sebesar 20,7 persen djelaskan oleh faktor lain yang tidak dimasukkan ke dalam model.

Hasil koefisien jalur pada hipotesis penelitian dapat digambarkan pada Gambar 3. berikut :

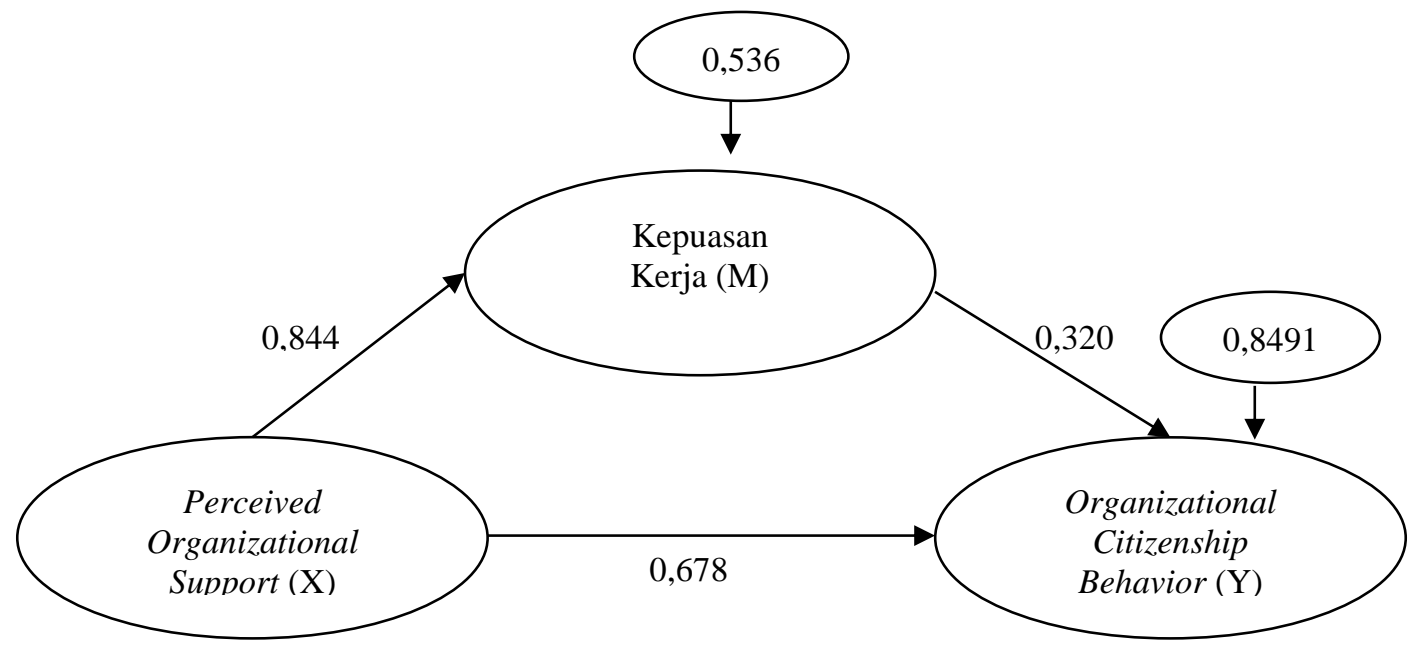

Gambar 3. Validasi Model Diagram Jalur Akhir

Sumber: Hasil Olahan Data, 2020

Berdasarkan diagram jalur pada Gambar 3, maka dapat dihitung besarnya pengaruh langsung dan pengaruh tidak langsung serta pengaruh total antar variabel. Perhitungan pengaruh antar variabel dirangkum dalam Tabel 10.

Tabel 10.

Pengaruh Langsung dan Pengaruh Tidak Langsung serta Pengaruh Total

\begin{tabular}{cccc}
\hline $\begin{array}{c}\text { Pengaruh } \\
\text { Variabel }\end{array}$ & $\begin{array}{c}\text { Pengaruh } \\
\text { Langsung }\end{array}$ & $\begin{array}{c}\text { Pengaruh Tidak Langsung Melalui } \\
\text { Kepuasan kerja } \\
(\text { Y1 })(\boldsymbol{\beta 1} \mathbf{\beta} \boldsymbol{\beta 3})\end{array}$ & Pengaruh Total \\
\hline $\mathrm{X} \rightarrow \mathrm{M}$ & 0,844 & - & 0,844 \\
$\mathrm{X} \rightarrow \mathrm{Y}$ & 0,678 & 0,270 & 0,678 \\
$\mathrm{M} \rightarrow \mathrm{Y}$ & 0,320 & - & 0,320 \\
\hline
\end{tabular}

Sumber: Hasil Olahan Data, 2020 
Berdasarkan hasil perhitungan diatas menunjukkan bahwa pengaruh langsung perceived organizational support terhadap kepuasan kerja adalah sebesar 0,844. Pengaruh langsung variabel perceived organizational support terhadap organizational citizenship behavior sebesar 0,678. Pengaruh langsung variabel kepuasan kerja terhadap organizational citizenship behavior sebesar 0,320. Hal ini berarti bahwa variabel organizational citizenship behavior lebih besar dipengaruhi oleh perceived organizational support dibandingkan kepuasan kerja. Sedangkan pengaruh tidak langsung variabel perceived organizational support terhadap organizational citizenship behavior melalui kepuasan kerja sebesar 0,270. Jadi pengaruh total variabel perceived organizational support terhadap organizational citizenship behavior melalui kepuasan kerja adalah sebesar 0,948.

Pengujian pengaruh tidak langsung variabel perceived organizational support (X) terhadap variabel organizational citizenship behavior (Y) melalui variabel kepuasan kerja $(\mathrm{M})$, dilakukan dengan rumus sebagai berikut :

$$
\begin{aligned}
& S_{b 1 b 3}=\sqrt{(0,320)^{2}(0,079)^{2}+(0,963)^{2}(0,130)^{2}+(0,079)^{2}(0,130)^{2}} \\
& S_{b 1 b 3}=0,128129 \\
& Z=\frac{b 1 b 3}{S b 1 b 3} \ldots \ldots \ldots \ldots \ldots \ldots \ldots \ldots \ldots \ldots \ldots \ldots \ldots \ldots \ldots \ldots \ldots \ldots \ldots \ldots \ldots \ldots \ldots \ldots \ldots \ldots \ldots \ldots \ldots \\
& Z
\end{aligned}
$$

Nilai Z hitung sebesar 2,4051 > 1,96. Artinya Kepuasan kerja (M) merupakan variabel yang memediasi Perceived Organizational Support (X) terhadap Organizational Citizenship Behavior (Y) pada PT. Marga Yumna Adventur.

Berdasarkan hasil analisis perceived organizational support terhadap kepuasan kerja diperoleh nilai Signifikansi sebesar 0,000 dengan nilai koefisien beta 0,844. Nilai Signifikansi 0,000 $<0,05$ mengindikasikan bahwa $\mathrm{H}_{0}$ ditolak dan $\mathrm{H}_{1}$ diterima. Hasil ini mempunyai arti bahwa perceived organizational support berpengaruh positif dan signifikan terhadap kepuasan kerja pada PT. Marga Yumna Adventur, dimana semakin baik penerapan perceived organizational support terhadap karyawan, maka kepuasan kerja karyawan akan meningkat. Berdasarkan hal tersebut maka hipotesis perceived organizational support berpengaruh positif terhadap kepuasan kerja dapat diterima pada PT. Marga Yumna Adventur. Hasil penelitian ini sesuai dengan penelitian Eisenberger et al. (2002), Novira dan Martono (2015), Paille et al. (2010), Robbins (2015), Han et al. (2012), Filipova (2011).

Ketika manajemen PT. Marga Yumna Adventur menghargai kontribusi dari karyawannya dengan memberikan imbalan finansial (berupa upah) dan non finansial (kesempatan promosi jabatan) yang sesuai dengan kinerja karyawan, maka karyawan akan merasa diperhatikan oleh perusahaan dan hal ini dapat meningkatkan kepuasan karyawan terhadap manajemen perusahaan. Karyawan juga akan merasa puas dengan perusahaan ketika manajemen PT. Marga Yumna Adventur memperhatikan kebutuhan karyawan, mendengarkan keluhan karyawan serta melakukan tindak lanjut terhadap keluhan tersebut. Kepedulian manajemen juga dapat diwujudkan dengan memberikan beban kerja yang sesuai dengan kemampuan yang dimiliki karyawan, jika karyawan sudah merasa bahwa 
pembagian pekerjaan adil antar karyawan maka hubungan antar karyawan juga dapat terjalin dengan baik. Selain itu pekerjaan sebagai pemandu wisata rafting memiliki risiko kecelakaan dalam bekerja, dengan adanya kepedulian manajemen yang diwujudkan dalam memberikan alat pengaman yang lengkap serta melengkapi karyawan dengan pengetahuan yang memadai tentang menanggulangi risiko pekerjaan akan membuat karyawan merasa diperhatikan dan membentuk persepsi positif karyawan terhadap manajemen.

Hasil analisis data mengungkapkan bahwa karyawan dengan perceived organizational support yang relatif tinggi dapat berimbas pada kepuasan kerja disebabkan pada aspek : adanya perhatian yang besar pada kinerja (skor 4,08), adanya kepeduli tentang kesejahteraan (skor 4,04), menghargai kontribusi (skor 4,04), memberitahu jika tidak melakukan pekerjaan dengan baik (skor 4,03), merasa bangga atas keberhasilan di dalam melakukan pekerjaan (skor 4,00), menghargai usaha ekstra yang diberikan (skor 3,98), adanya perhatian segala keluhan (skor 3,90), adanya kepedulian dengan kepuasan terhadap pekerjaan yang dilakukan $(3,87)$.

Berdasarkan hasil analisis pengaruh kepuasan kerja terhadap organizational citizenship behavior (OCB) diperoleh nilai signifikansi sebesar 0,017 dengan nilai koefisien beta 0,320 . Nilai Signifikansi $0,017<0,05$ mengindikasikan bahwa $\mathrm{H}_{0}$ ditolak dan $\mathrm{H}_{2}$ diterima. Hasil ini mempunyai arti bahwa kepuasan kerja berpengaruh positif dan signifikan terhadap organizational citizenship behavior (OCB) pada PT. Marga Yumna Adventur, karena semakin tinggi penerapan kepuasan kerja maka OCB semakin meningkat. Berdasarkan hal tersebut maka hipotesis kepuasan kerja berpengaruh positif terhadap OCB dapat diterima pada PT. Marga Yumna Adventur. Hasil penelitian ini sesuai dengan penelitian Noruzy et al. ( 2011), Kencanawati (2014), Khan dan Ghufran (2018), Dewanggana dkk (2016), Wijaya dan Sutanto (2014), Ngadiman (2013), Osman et al. (2015).

Karyawan yang puas dengan manajemen PT. Marga Yumna Adventur, akan dengan sadar mendedikasikan waktu dan tenaga untuk perusahaan yang ditunjukkan melalui kepatuhan terhadap segala peraturan yang diterapkan oleh manajemen PT. Marga Yumna Adventur. Karyawan juga akan turut serta dalam mengembangkan perusahaan ke arah yang lebih baik karena adanya keterikatan dengan perusahaan, hal ini ditunjukkan dengan menjaga hubungan antar karyawan dan juga membantu sesama karyawan yang terlihat kesulitan dalam menyelesaikan pekerjaanya.

Hasil analisis data mengungkapkan bahwa karyawan dengan kepuasan kerja yang relatif tinggi dapat berimbas pada organizational citizenship behavior disebabkan pada aspek : adanya hubungan anatar rekan kerja terjalin dengan baik (skor 4,14), pekerjaan yang dibebankan sesuai dengan kemampuan (skor 4,04), puas dengan kesempatan yang diberikan untuk mendapatkan promosi (skor 4,03), adanya pengawasan menyeluruh pekerjaan yang dilakukan (skor 3,90), adanya upah yang diterima sudah sesuai dengan beban pekerjaan (skor 3,75).

Hasil pengujian hipotesis pengaruh perceived organizational support terhadap organizational citizenship behavior (OCB) diperoleh nilai signifikansi sebesar 0,000 dengan nilai koefisien beta 0,678. Nilai Signifikansi 0,000<0,05 mengindikasikan bahwa $\mathrm{H}_{0}$ ditolak dan $\mathrm{H}_{3}$ diterima. Hasil ini mempunyai arti 
bahwa perceived organizational support berpengaruh positif dan signifikan terhadap OCB pada PT. Marga Yumna Adventur, karena karyawan yang merasakan dukungan dari perusahaan dimana karyawan bekerja akan cenderung melakukan perilaku ekstra dalam bekerja. Berdasarkan hal tersebut maka hipotesis perceived organizational support berpengaruh positif terhadap OCB dapat diterima pada PT. Marga Yumna Adventur. Hasil penelitian ini sesuai dengan penelitian Sesan dan Nejat (2012), Lee et al. (2013), Najafi et al. (2011), Alkerdawy (2014), Liang dan Crant (2010), Rivanda (2013), Osman et al. (2015).

Ketika karyawan PT. Marga Yumna Adventur merasakan dukungan yang diberikan dari pihak menajemen telah sesuai harapan mereka, maka dengan sukarela karyawan akan memberikan kinerja terbaiknya sebagai bentuk balasan atas apa yang diberikan perusahaan. Hal ini diwujudkan dengan karyawan yang datang tepat waktu sesuai aturan jam kerja yang diterapkan perusahaan dan mendukung perubahan dan perkembangan perusahaan kearah yang lebih baik.

Hasil analisis data mengungkapkan bahwa karyawan dengan perceived organizational support yang relatif tinggi dapat berimbas pada organizational citizenship behavior disebabkan pada aspek : adanya perhatian yang besar pada kinerja (skor 4,08), adanya kepeduli tentang kesejahteraan (skor 4,04), menghargai kontribusi (skor 4,04), memberitahu jika tidak melakukan pekerjaan dengan baik (skor 4,03), merasa bangga atas keberhasilan di dalam melakukan pekerjaan (skor 4,00 ), menghargai usaha ekstra yang diberikan (skor 3,98), adanya perhatian segala keluhan (skor 3,90), adanya kepedulian dengan kepuasan terhadap pekerjaan yang dilakukan $(3,87)$.

Hasil uji menunjukan bahwa nilai Z hitung sebesar 2,4051 > 1,96 dengan nilai signifikansi $0,000<0,05$, yang artinya kepuasan kerja merupakan variabel yang memediasi perceived organizational citizenship terhadap organizational citizenship behavior (OCB) pada PT. Marga Yumna Adventur atau dengan kata lain perceived organizational citizenship berpengaruh secara tidak langsung terhadap organizational citizenship behavior (OCB) melalui kepuasan kerja.

Ketika manajemen PT. Marga Yumna Adventur memberi dukungan terhadap karyawan baik dalam bentuk dukungan secara finansial (pemberian gaji yang sesuai dengan beban dan risiko kerja) maupun dukungan non finansial (seperti pemberian pelatihan dan pengetahuan akan risiko kerja) maka karyawan akan menghasilkan kepuasan kerja yang tinggi dan tekad untuk memiliki peran ekstra di luar pekerjaannya. Persepsi dukungan organisasi yang tinggi akan meningkatkan kepuasan kerja yang dirasakan oleh karyawan dan ketika karyawan merasakan kepuasan kerja yang tinggi karyawan akan berusaha untuk melakukan hal yang menguntungkan bagi organisasi

Penelitian ini mendukung beberapa hasil penelitian sebelumnya yang dilakukan oleh Maula dan Afrianty (2017) menyimpulkan bahwa semakin baik perceived organizational support maka kemudian dapat mempengaruhi kepuasan kerja sehingga dapat meningkatkan OCB pada karyawan. Penelitian lain oleh Islam et al. (2014) menyatakan bahwa kepuasan kerja dapat menjadi variabel mediasi dalam hubungan antara perceived oganizational support dan organizational citizenship behavior. kepuasan kerja menjadi variabel mediasi antara Perceived 
Organizational Support dengan Organizational Citizenship Behavior (Waileruny, 2014).

Hasil penelitian ini mendukung teori yang digunakan sebagai dasar dalam pembuatan hipotesis bahwa perceived organizational support mempengaruhi terhadap organizational citizenship behavior, selain itu peran kepuasan kerja mampu memediasi hubungan perceived organizational support terhadap organizational citizenship behavior. Ketika karyawan merasa mendapat dukungan dari organisasi dan disertai dengan kepuasan kerja yang tinggi, maka akan dapat meningkatkan perilaku organizational citizenship behavior. Hal ini menunjukan bahwa hasil penelitian memperkuat teori yang digunakan yaitu social exchange theory atau teori pertukaran sosial.

Berdasarkan hasil pengujian sebelumnya, bahwa social exchange theory terdukung dalam penelitian ini, karena semua hipotesis berpengaruh positif dan signifikan. Pertukaran dapat terjadi apabila dua belah pihak antara karyawan dan organisasi mampu memberikan sesuatu hal satu sama lain. Maka dari itu, karyawan akan mau melakukan perilaku extra-role ketika mereka telah diperlakukan dengan baik oleh organisasi, dan mereka akan cenderung untuk besikap dan berperilaku lebih positif terhadap organisasi

Pada variabel perceived organizational support, karywan PT. Marga Yumna Adventur menilai bahwa variabel ini meningkatkan perilaku extra-role. Oleh karena itu perlu adanya dukungan dari organisasi dan kepedulian akan kesejahteraan karyawan.

Pada variabel kepuasan kerja, karyawan PT. Marga Yumna Adventur menilai bahwa variabel ini meningkatkan perilaku extra-role. Oleh karena itu tingkat kepuasan kerja karyawan harus diperhatikan oleh organisasi agar karyawan bekerja dengan efektif dan tercapainya tujuan organisasi

\section{SIMPULAN}

Simpulan dalam penelitian ini adalah perceived organizational support berpengaruh positif dan signifikan terhadap kepuasan kerja, hal ini berarti semakin banyak dukungan yang diberikan oleh manajemen PT. Marga Yumna Adventur maka kepuasan karyawan akan meningkat. Kepuasan kerja berpengaruh positif dan signifikan terhadap organizational citizenship behavior, hal ini berarti bahwa semakin tinggi tingkat kepuasan yang dirasakan karyawan PT. Marga Yumna Adventur maka semakin tinggi pula OCB yang dimiliki karyawan. Perceived organizational support berpeharuh positif dan signifikan terhadap organizational citizenship behavior, ini berarti bahwa semakin banyak dukungan yang diberikan oleh manajemen PT. Marga Yumna Adventur maka perilaku OCB karyawan akan meningkat. Kepuasan kerja berpengaruh positif dan signifikan memediasi peran perceived organizational support terhadap organizational citizenship behavior hal ini berarti semakinn banyak dukungan yang diberikan oleh manajemen PT. Marga Yumna Adventur maka kepuasan karyawan akan meningkat dan kemudian akan menimbulkan perilaku OCB yang lebih baik pada karyawan.

Berdasarkan hasil analisis penelitian, maka disarankan bagi perusahaan untuk lebih menghargai setiap usaha ekstra yang diberikan karyawan dalam 
melaksanakan pekerjaannya, sehingga akan menimbulkan rasa kebermaknaan serta perasaan senang dan karyawan merasa dianggap penting oleh perusahaan. Perusahaan sebaiknya memberikan reward bagi karyawan yang berprestasi dalam melakukan pekerjaannya, sehingga kepuasan kerja akan terus berada pada titik terbaik dimana secara langsung akan mempengaruhi kinerja perusahaan. Penghargaan yang dimaksud dapat berupa penghargaan finansial (bonus, insentif) maupun non finansial seperti promosi jabatan ataupun pemberian sertifikat sebagai tanda bukti karyawan telah bekinerja dengan baik.

Karyawan pada PT. Marga Yumna Adventur harus lebih meningkatkan perilaku OCB terutama mengenai perubahan dan perkembangan dalam organisasi, sehingga karyawan dapat memiliki keinginan untuk perubahan dan perkembangan dalam organisasi. Agar dapat mewujudkan visi, misi dan tujuan dari PT. Marga Yumna Adventur. Hal ini dapat dilakukan dengan bersifat terbuka atas segala kebijakan dan peraturan yang akan diterapakan, dengan sifat terbuka tersebut maka tidak akan timbul kecurigaan diantara karyawan dan manajemen perusahaan.

Pihak PT. Marga Yumna Adventur harus lebih mendengarkan dan memperhatikan keluhan yang dirasakan karyawan dalam pekerjaannya agar karyawan lebih memberikan kontribusi terhadap perusahaan, hal ini dapat dilakukan dengan melakukan briefing berkala untuk mendengar pendapat dan keluhan langsung dari karyawan, dan kemudian perusahaan juga harus melakukan tindak lanjut terhadap keluhan karyawan tersebut sebagai bukti bahwa perusahaan memiliki kepedulian pada karyawan.

Pihak PT. Marga Yumna Adventur harus meningkatkan pengawasan menyeluruh terhadap karyawan, agar bisa mengontrol semua kinerja karyawan yang sesuai dengan standar operasional prosedur (SOP) perusahaan. PT. Marga Yumna Adventur diharapkan memberikan dukungan pada karyawan terkait risiko kerja yang dihadapi karyawan seperti memberikan asuransi yang dapat memberikan jaminan perlindungan ketika karyawan mengalami kecelakaan kerja, asuransi dapat berupa BPJS ketenakerjaan dan BPJS kesehataan maupun asuransi swasta yang memiliki penawaran produk dapat memberikan perlindungan pada karyawan PT. Marga Yumna Adventur ketika terjadi kecelakaan kerja.

\section{REFERENSI}

Alkerdawy, M. M. A. (2014). The Mediating Effects of Duty Orientation on the Relationship between Perceived Organizational Support and Organizational Citizenship Behavior in the Public Banks of Egypt. International Journal of Business and Management, 9(8), 155-169.

Arif, B., Samuel, A., \& Dea, P. (2014). Does Job Satisfaction Influence Organizational Citizenship Behavior? An Empirical Study in Selected 4-Star Hotels in Jakarta, Indonesia. Rev. Integr. Bus. Econ. Res, 3(1), 130-149.

Charmiati, P. G. H. A., \& Surya. (2019). Pengaruh Kepuasan Kerja Terhadap Organizational Citizenship Behavior (OCB) dengan Komitmen Organisasional sebagai Variabel Mediasi. E-Jurnal Manajemen Unud, 3(1), 
$130-149$.

Dewanggana, Dhatu, B., Paramita, P. D., \& Haryono, A. T. (2016). Pengaruh

Komitmen Organisasi, Kepuasan Kerja, Budaya Organisasi terhadap Organizational Citizenship Behavior (OCB) yang berdampak pada Prestasi Kerja Karyawan Studi pada PT. PLN APP Semarang. Journal of Management, 2(2), 222-250.

Eisenberger, R., Stinglhamber, F., Vandenberghe, C., Sucharski, I. L., \& Rhoades, L. (2002). Perceived Supervisor Support: Contributions To Perceived Organizational Support and Employee Retention. Journal of Applied Psychology, 87(3), 565-573.

Filipova. (2011). Relationship Among Ethical Climates Perceived Organzatonal Support and Intent to Leave for Licensed Nurses and Skilled Nursing Facilities. Journal of Applied Gerontology, 20(10), 650-715.

Han, S. T., Nugroho, A., Kartika, E. W., \& Kaihatu, T. S. (2012). Komitmen Afektif Dalam Organisasi Yang Dipengaruhi Perceived Organizational Support dan Kepuasan Kerja. Jurnal Manajemen Dan Kewirausahaan North America, 14(2), 109-117.

Harper, P. J. (2015). Exploring Forms of Organizational Citizenship Behaviors (OCB): Antecedents and Outcame. Journal of Management and Marketing Research, 18(3), 225-250.

Islam, T., Khan, S. R., Ahmad, U. N. U., \& Ahmed, I. (2014). Exploring the Relationship between POS, OLC, Job Satisfaction and OCB. Procedia-Social and Behavior Sciences, 1(1), 33-40.

Karavardar, G. (2014). Perceived Organizational Support, Psychological Empowerment, Organizational Citizenship Behavior, Job Performance and Job Embeddedness: A Research on the Fast Food Industry in Istanbul, Turkey. International Journal of Business and Management, 9(4), 131-139.

Kencanawati, A. A. . (2014). Gaya Kepemimpinan, Komitmen Organisasi dan Kepuasan Kerja memengaruhi Organizational Citizenship Behavior pada PT. (BPR) Cahaya Bina Putra Kerobokan Badung. Jurnal Manajemen Dan Kewirausahaan, 10(1), 44-45.

Khan, R. ., \& Ghufran, H. (2018). The Mediating Role of Perceived Organizational Support between Qualitative Job Insecurity, Organizational Citizenship Behavior and Job Performance. J Entrepren Organiz Manag, 7(1), 2-7.

Kusuma, A. D., Sunuharjo, B. S., \& Iqbal, M. (2018). Pengaruh Lingkungan Kerja Fisik Dan Non Fisik Terhadap Kinerja Karyawan Dengan Variabel Mediator 
Kepuasan Kerja (Studi Pada Karyawan PT Telkomsel Branch Malang). Jurnal Administrasi Bisnis (JAB), 55(2), 68-74.

Lakshmi, P. A. V., \& Simarmata, N. (2015). Hubungan antara Iklim Organisasi dengan Perilaku Kewargaan Organisasi Pada Karyawan di Perusahaan Ritel. Jurnal Psikologi Udayana, 2(1), 25-37.

Lee, U. ., Kim, H. K., \& Kim, Y. . (2013). Determinants of Organizational Citizenship Behavior and Its Outcomes. Global Business and Management Research. An International Journal, 5(1), 54-65.

Liang, \& Crant. (2010). The Role of Proactive Personality in Job Satisfaction and Organizational Citizenship Be- havior: A Relational Perspective. Journal of Applied Psychology, 95(2), 395-404.

Maula, L. A., \& Afrianty, T. W. (2017). Perceived Organizational Support dan Pengaruhnya terhadap Organizational Citizenship Behavior dengan Job Satisfaction Sebagai Variabel Intervening (Studi pada Karyawan Jawa Timur Park 1). Jurnal Administrasi Bisnis (JAB), 50(4), 556-644.

Mehboob, F., \& Bhutto, N. A. (2012). Job Satisfaction as a Predictor of Organizational Citizenship Behavior A Study of Faculty Members at Business Institutes. Interdiciplinary Journal of Contemporary Research in Business, 3(9), 1447-1455.

Najafi, S., Noruzy, A., Azar, H. K., Nazari-Shirkouhi, S., \& Dalvand., M. R. (2011). Investigating the Relationship Between Organizational Justice, Psychological Empowerment, Job Satisfaction, Organizational Commitment and Organizational Citizenship Behavior: An Empirical Model. African Journal of Business Management, 5(13), 5241-5248.

Ngadiman. (2013). Influence of Work Satisfaction, and Organizational Commitment to The Organizational Citizenship Behavior of Lecturers at Faculty of Teachers Training and Education, Sebelas Maret University, Surakarta,. Educational Research International, 1(3), 352-365.

Noruzy, A., Shatery, K., Rezazadeh, A., \& Hatami-Shirkouh, L. (2011). Investigation the Relationship Between Organizational Justice, and Organizational Citizenship Behavior: The Mediating Role of Perceived Organizational Support. Indian Journal of Science and Technology, 4(7), 842847.

Novira, L., \& Martono, S. (2015). Pengaruh Persepsi Dukungan Organisasi Pada Perilaku Kewargaan Organsasional Dengan Kepuasan Kerja Sebagai Variabel Intervening. Management Analysis Journal, 4(3), 181-188. 
Oladunmoye, E. O. (2017). A Regression Analysis of Perceived Organizational Support, Interpersonal Relationship and Employee Turnover Intention in Southwest Nigeria. International Journal of Information, Business and Management, 9(3), 146-274.

Osman, A., Othman, Y. H., Sohel Rana, S. M., Solaiman, M., \& Lal, B. (2015). The Influence of Job Satisfaction, Job Motivation and Perceived Organizational Support towards Organizational Citizenship Behavior (OCB): A Persective of American-Based Organization in Kulim, Malaysia. Canadian Center of Science and Education, 11(21), 226-244.

Paille, P., Bourdeau, L., \& Galois, I. (2010). Support, Trust, Satisfaction, Intent to Leave, and Citizenship at Organizational Level. International Journal of Organitazional Analyzis, 18(1), 41-58.

Rivanda, F. (2013). Perlakuan-Perlakuan Dari Organisasi Yang Diterima Oleh Karyawan Ditangkap Sebagai Stimulus Yang Diorganisir dan Diinterprestasikan Menjadi Persepsi Atas Dukungan Organisasi. Jurnal Manajemen Universitas Negeri Padang, 2(1), 1-12.

Robbins, S. P. (2015). Perilaku Organisasi. Retrieved from https://kin.perpusnas.go.id/DisplayData.aspx

Saeed, I., Waseem, M., Sikander, S., \& Rizwan, M. (2014). The Relationship of Turnover Intention with Job Satisfaction, Job Performance, Leader Member Exchange, Emotional Intelligence and Organizational Commitment. International Journal of Learning \& Development, 4(2), 242256.

Sanusi Alberto Chandra, Ariana, \& Ariani. (2018). Tingkat Organizational Citizenship Behavior (OCB) Karyawan Di Four Points Seminyak. Jurnal Kepariwisataan Dan Hospitalitas, 2(1), 61-83.

Sesan, H., \& Nejat, B. (2012). Impact of Satisfaction and Commitment on Teachers' Organizational Citizenship. Educational Psychology, 32(4), 475491.

Soegandhi, Marchella, V., Sutanto, E. M., \& Setiawan, R. (2013). Pengaruh Kepuasan Kerja dan Loyalitas Kerja Terhadap Organizational Citizenship Behavior pada Karyawan PT. Surya Timur Sakti Jatim. Agora, 1(1), 356-365.

Tripathi, P., \& Pandey, M. K. (2017). Examining the Relationship Between WorkFamily Conflict, Job Satisfaction and Employee's Turnover Intention. Journal of Psychosocial Research, 12(2), 451-459.

Waileruny, H. T. (2014). Perceived Organizational Support, Job Satistaction Dan Organizational Citizenship Behavior Pada Pt. Bank Maluku Cabang Utama 
Kota Ambon. Agora, 2(2), 356-365.

Widyaningrum, R. (2010). Pengaruh Sumber Daya Manusia dan Informasi Teknologi Pemanfaatan Keandalan dan Ketepatanwaktu Pelaporan Keuangan Pemerintah dengan Variabel Intervening Pengendalian Internal Akuntansi. Simposium Nasional Akuntansi (SNA) XIII Purwokerto, 1(2), 226-232.

Wijaya, \& Sutanto. (2014). Pengaruh Komitmen Organisasioanl dan Kepuasan Kerja Karyawan Terhadap Organizational Citizenship Behaviour di PT. XYZ Surabaya. Agora, 2(2), 1-6.

Wong, Y.-W., \& Wong, Y.-T. (2017). The Effects of Perceived Organisational Support and Affective Commitment on Turnover Intention: A Test of Two Competing. Journal of Chinese Human Resource Management, 8(1), 2-21. 